\title{
SHORT-TERM RESPONSE OF JORDAN'S SALAMANDER TO A SHELTERWOOD TIMBER HARVEST IN WESTERN NORTH CAROLNA
}

\author{
Chad E. Bartman \\ Department of Geography \\ University of Georgia \\ Athens, Georgia 30602 \\ chadbartman@hotmail.com \\ Kathleen C. Parker' \\ Department of Geography \\ University of Georgia \\ Athens, Georgia 30602 \\ kcparker@arches.uga.edu \\ joshua Laerm** \\ Georgia Museum of Natural History \\ University of Georgia \\ Athens, Georgia 30602 \\ Timothy S. McCay \\ Department of Biology \\ Colgate University \\ Hamilton, New York 13346 \\ tmccay@mail.colgate.edu
}

\begin{abstract}
The effects of shelterwood cutting on the abundance of Jordan's salamander (Plethodon jordani) in western North Carolina were examined during 1997 and 1998. Terrestrial salamander assemblages were sampled before, immediately after, and one year after timber harvest on control and treatment plots to estimate abundance. We also surveyed salamanders immediately after the harvest along transects radiating out from cut plots to determine whether cutting triggered salamander emigration from disturbed plots. Both before and after timber harvest, the site was strongly dominated by Jordan's salamander. No significant effects of initial shelterwood cutting on Jordan's salamander abundance were apparent after timber harvest. Abundance of this species decreased from precutting to post-cutting sampling on both control and treatment plots, which likely reflected the drought that characterized both post-cutting sampling periods, but not pre-cutting sampling. No emigration of salamanders from the cut plots was detected after timber harvest. These findings suggest that at a stand scale, shelterwood harvests may pose less of a short-term threat to salamander populations than clearcutting, but more study is necessary to assess broad-scale tradeoffs between harvest yield and biological impacts associated with alternative timber harvest methods. [Key words: salamander, timber harvesting, North Carolina.]
\end{abstract}

${ }^{*}$ Corresponding author.

${ }^{*}$ Deceased. 


\section{INTRODUCTION}

A number of studies have reported adverse effects of forest clearcutting on amphibian communities in both the Pacific Northwest (Corn and Bury, 1988; Aubry and Hall, 1991; Bury et al., 1991) and the southern Appalachians (Pough et al., 1987; Ash, 1988; Petranka et al., 1993, 1994). Bury (I 983) described a scenario for salamander declines for redwood (Sequoia sempervirens) forests in the Pacific Northwest that also can be applied to many other forest types in mountainous areas (Buhlmann et al., 1988; Raphael, 1988). Clearcutting removes the forest canopy, leading to increased light penetration; this in turn results in accelerated evaporative water loss from the soil and understory (Dupuis et al., 1995). A reduction in the leaf litter layer after timber harvest may cause further desiccation of the soil (Ash, 1995, 1997). Consequently, in comparison to unaltered forest stands, there are greater fluctuations in temperature and humidity, which are intolerable to many amphibian species (Feder, 1983).

Research on salamander communities in the southern Appalachians has been consistent with this scenario (Ash, 1988; Petranka et al., 1993, 1994; Harpole and Haas, 1999), although results have been somewhat varied regarding the effects of clearcutting on the severity of salamander population declines and estimated recovery time necessary to reach pre-harvest abundances. Petranka et al. (1993) reported declines in both salamander density and richness on clearcuts in the southern Appalachians. Petranka et al. (1994) suggested that terrestrial salamanders are almost completely eliminated after clearcutting and that a SO-70 year recovery period is necessary to regain and maintain pre-cutting abundance levels, a recovery time also supported by Ford et al. (2001). Others have suggested, however, that the recovery time for salamander populations on clearcut sites in the southern Appalachians is much shorter (Ash and Bruce, 1994; Ash, 1997; Harper and Guynn, 1998; Ash and Pollock, 1999). Although some work has compared effects of alternative methods of timber harvest on salamanders in other regions (e.g., Pough et al., 1987; Dodd, 1991; Messere and Ducey, 1998; Grialou et al., 2000; Ross et al., 2000), most studies in the southern Appalachians have focused on clearcuts (but see Harpole and Haas, 1999 for an exception). Additional studies on selective timber harvest and associated effects on salamander populations are needed (deMaynadier and Hunter, 1995).

Post-logging amphibian population declines have typically been attributed to mortality rather than emigration, with estimated mortality as high as $80 \%$ (Petranka et al., 1993). Although Ash and Bruce (I 994) suggested emigration as an explanation for decreases in salamander abundance after timbering, little investigation of post-logging salamander emigration has been made. In one of the few studies that has reported salamander emigration to adjacent forest stands after a clearcut, Raymond and Hardy (1991) found that clearcutting lowered survival rates of adult mole salamanders (Ambystomatalpoideum) and forced adults to emigrate to adjacent, less suitable forest stands. Although Raymond and Hardy's research dealt with an aquatic-breeding species, it suggests that both emigration and. increased mortality may occur in some salamander species in cut areas; more work is needed to deter- 
mine how widespread post-logging emigration is among terrestrial salamanders in the Southeast.

Most studies of salamander abundance in harvested areas have been based on a chronosequence of cut stands, which involves simultaneously sampling a number of stands of different ages. Chronosequencing requires assumptions about the homogeneity of uncut and cut plots that may be unfounded; deMaynadier and Hunter (1995) instead stressed the importance of repeated pre-and post-harvest sampling of salamander populations to determine the effects of timber harvest. In this paper, we report results from research that used repeated sampling of the same stand before and after timber harvest to determine the short-term response of salamander populations to the initial cutting in a shelterwood harvest in the southern Appalachians. The shelterwood method of regeneration involves the removal of overstory trees in at least two harvests. Initial cuttings are incomplete, and residual trees promote natural regeneration and shelter seedlings from desiccation and wind damage (Smith et al., 1997). As such, the retention of overstory trees can mitigate against some of the harsh microclimatic conditions in clearcuts (Petranka et al., 1993).

Specific research objectives of this study were: (1) to estimate changes in salamander abundance in both cut and uncut stands that occurred immediately after and approximately one year after logging; and (2) to estimate the extent of salamander emigration from cut stands following harvest. Our initial intent was to examine changes in salamander community composition and abundance of constituent species; however, because Jordan's salamander strongly dominated pre-and post-harvest communities, we have limited our statistical analysis to that species and present merely qualitative observations on the other species present. Plethodon species are entirely terrestrial and must rely on forests to meet their needs in all life stages; therefore, they are potentially sensitive to adverse changes in forest microclimate and microhabitat associated with timber harvest (deMaynadier and Hunter, 1995; Herbeck and Larsen, 1999). Consequently, they are a particularly important group of salamanders to examine.

\section{STUDY AREA}

This research was conducted in the Wine Spring Creek Ecosystem Management Demonstration Unit, Nantahaia National Forest, west of Franklin, North Carolina (35.18" N, 83.56" W). The study site was 5.83 ha in size and occupied a north-facing slope from 1370 to $1550 \mathrm{~m}$ in elevation. The site was cut during the summer of 1997 in the initial stage of a shelterwood harvest. This harvest involved felling $70-$ $85 \%$ of the overstory basal area, from an initial value of approximately $27 \mathrm{~m}^{2} / \mathrm{ha}$ to a residual value of $4-8 \mathrm{~m}^{2} / \mathrm{ha}$. An effort was made to retain oaks (Quercus spp.) in the residual overstory to maintain hard mast production and the representation of this genus in subsequent regeneration. Residual trees were widely spaced, and all felled trees were retained at the site.

Forest composition of the study area represents a transition from mesic-slope oak-chestnut to high-elevation northern hardwoods, dominated by chestnut oak (Quercus prinus), white oak (Q. alba), American beech (Fagus grandifolia), red 
maple (Acer rubrum), and occasional Carolina hemlock (Tsuga caroliniana). The forest floor of the site was littered with American chestnut (Castanea dentata) trees killed by chestnut blight in the early 1900s. Mean monthly precipitation at Wayah Bald, North Carolina (I $632 \mathrm{~m}$ elevation, $3.5 \mathrm{~km}$ from the study area) ranges from a low of $\mathbf{1 0 1 . 6} \mathrm{mm}$ in October to a high of $\mathbf{2 1 2 . 5} \mathrm{mm}$ in February (National Climatic Data Center, 1998). Mean monthly temperature at Coweeta, North Carolina $(685 \mathrm{~m}$ elevation, $20 \mathrm{~km}$ from the study area) ranges from $1.8^{\circ} \mathrm{C}$ in January to $21.5^{\circ} \mathrm{C}$ in July (Owenby and Ezell, 1992).

\section{METHODS}

Salamanders were sampled in planned cut (treatment) and uncut (control) areas before, directly after, and approximately one year after cutting with a quadrat sampling method (Jaeger and Inger, 1994). Three pairs of $10 \times 10 \mathrm{~m}$ grids (six grids total) were placed within and around the periphery of the shelter-wood site and permanently marked. Grids were placed to ensure sampling of both cut and uncut areas. Cut and uncut grids within a pair were located at least $20 \mathrm{~m}$ apart so that natural home ranges of resident terrestrial salamander species would not exceed the distance between grid pairs (Nishikawa, 1990).

Standard mark-recapture methods were used to sample the salamander populations on the grids (Otis et al., 1978; White et al., 1982). This procedure bases population estimates on the recapture histories throughout a sampling period after individuals are marked upon their initial capture. Each grid was subdivided into one-meter cells. During each night of sampling, each ceil of each grid was visually inspected for salamanders for approximately one minute. Salamanders found by visual inspection were captured by hand and released after marking; logs, leaf litter, and other debris were not disturbed during sampling to avoid habitat destruction and its adverse effects on subsequent sampling (Harpole and Haas, 1999). Each adult salamander with a snout-vent length $>20 \mathrm{~mm}$ that was captured during precutting sampling was marked individually by toe clipping for identification (Donnelly and Guyer, 1994; Donnelly et al., 1994) and the cell where it was encountered was recorded. Individuals too small for individual toe clipping $\quad<20 \mathrm{~mm}$ snout-vent length) were given a group mark to provide identification of capture on subsequent sampling nights. Group marks were specific to the type of grid (i.e., control versus treatment) where they were captured and the sampling period. Snout-vent length and species of captured salamanders were noted. All post-cutting sampling was conducted in the permanently marked grids with the same procedure used in pre-cutting sampling. Pre-cutting sampling was conducted for eight nights during 1997 (June 30-July 9) and post-cutting sampling was done for seven nights during each of 1997 (August Z-September 2) and 1998 (June 30-August 12).

Additional sampling for emigration was conducted for five nights after the 1997 post-cutting abundance sampling (September 19,20, 26-28) in strip-plots arranged along two transects radiating out from cut grids perpendicular to the grid boundaries. One transect ran from the grid into the closest non-cut area (including at least $10 \mathrm{~m}$ of the non-cut area) and the second transect ran from the sampling grid downslope out of the cut area. Strip-plots were $10 \times 2 \mathrm{~m}$ and were arranged every 
$10 \mathrm{~m}$ along each transect (perpendicular to the transect), for a total of 33 plots (from 4-8/line, depending on proximity to the nearest non-cut area). Plots were searched for salamanders; all salamanders caught on the emigration transects were inspected for marks and their location along the transect was noted.

Mark-recapture data were analyzed with the program CAPTURE (White et al., 1982), which uses individual capture histories to determine goodness-of-fit of several closed-population models; the best model is then used to estimate population abundance for each grid for each sample period (Otis et al., 1978; White et al., 1982). We chose the most suitable model based on the model-selection criterion calculated by program CAPTURE from the results of goodness-of-fit tests (White et al., 1982). Because model $M_{\text {th }}$, which allows detection probabilities to vary among individuals (e.g., due to sex or social dominance) and with time, was most suitable for the majority of analyses (i.e., grid-time combinations), we decided to adopt this model for all estimates of Jordan's salamander abundance. Although this model assumes a closed population, Kendall (1999) demonstrated that random movement into and out of study areas does not bias population estimates. The capture rates for the other species were too low for accurate abundance estimates; therefore, data for these species were summarized as capture numbers rather than abundances.

A repeated-measures analysis of variance (ANOVA) was used to test for differences in Jordan's salamander abundance over time (i.e., pre- versus post-cutting), treatment (i.e., cut versus uncut), and interactions between time and treatment. The main effect of concern in this analysis was the interaction between time and treatment; significant differences in Jordan's salamander abundance due to this effect would indicate a change in abundance associated with the shelterwood cutting relative to control plots. The Greenhouse-Geisser adjustment was used to correct degrees of freedom for temporal autocorrelation (Milliken and Johnson, 1992). It has been noted (deMaynadier and Hunter, 1995) that studies of effects of timber harvest on salamander populations often have unavoidable shortcomings in their experimental designs that limit the statistical power to identify significant effects of timber harvest. Stressing the costs associated with a type II error in this context (i.e., failure to reject a null hypothesis that should be rejected), they suggested elevating the acceptable level of a type lerror in salamander studies. We followed their suggestion and used $p<0.10$ in our ANOVA to assess significance.

\section{RESULTS}

During the 22 days of sampling, 1183 salamanders were toe-clipped on the six sampling grids. The number of individuals that were captured and marked on each grid differed greatly from night to night. More individuals typically were marked during pre-cutting sampling (range: I-68 salamanders per grid) than during both post-cutting sampling periods (0-33 salamanders per grid).

Five species of salamanders were identified on the grids during the study period (Table 1). These were Jordan's salamander, Ocoee salamander (Desmognathus ocoee), Blue Ridge two-lined salamander (Eurycea wilderae), pygmy salamander (D. wrighti), and red-spotted newt (Notophthalmus viridescens). Red-spotted newts 
Table 1. Total Numbers ${ }^{\mathrm{a}}$ of Different Species of Salamanders Captured

on Control and Treatment Grids during the Three Sampling Periods, Wine Spring Creek Watershed

\begin{tabular}{|c|c|c|c|c|c|c|}
\hline \multirow[b]{2}{*}{ Species } & \multicolumn{2}{|c|}{ Precutting 1997} & \multicolumn{2}{|c|}{ Post-cutting 1997} & \multicolumn{2}{|c|}{ Post-cutting 1998} \\
\hline & Control ${ }^{b}$ & Treatment $^{b}$ & Control & Treatment & Control & Treatment \\
\hline Jordan's salamander & $\begin{array}{c}243 \\
(75.2)\end{array}$ & $\begin{array}{l}286 \\
(78.1)\end{array}$ & $\begin{array}{r}169 \\
(84.1)\end{array}$ & $\begin{array}{c}110 \\
(85.3)\end{array}$ & $\begin{array}{c}176 \\
(88.0)\end{array}$ & $\begin{array}{c}74 \\
(82.2)\end{array}$ \\
\hline Ocoee salamander & $\begin{array}{c}61 \\
(18.9)\end{array}$ & $\begin{array}{c}61 \\
(16.7)\end{array}$ & $\begin{array}{r}30 \\
(14.9)\end{array}$ & $\begin{array}{c}16 \\
(12.4)\end{array}$ & $\begin{array}{c}21 \\
(10.5)\end{array}$ & $\begin{array}{c}14 \\
(15.6)\end{array}$ \\
\hline $\begin{array}{l}\text { Blue Ridge two-lined } \\
\text { salamander }\end{array}$ & $\begin{array}{c}14 \\
(4.3)\end{array}$ & $\begin{array}{c}16 \\
(4.4)\end{array}$ & $\begin{array}{c}2 \\
(1.0)\end{array}$ & $\begin{array}{c}3 \\
(2.3)\end{array}$ & $\stackrel{2}{(1.0)}$ & $\begin{array}{c}2 \\
(2.2)\end{array}$ \\
\hline Pygmy salamander & $\begin{array}{c}5 \\
(1.5)\end{array}$ & $\begin{array}{c}3 \\
(0.8)\end{array}$ & $\begin{array}{c}0 \\
(0.0)\end{array}$ & $\begin{array}{c}0 \\
(0.0)\end{array}$ & $\begin{array}{c}1 \\
(0.5)\end{array}$ & $\begin{array}{c}0 \\
(0.0)\end{array}$ \\
\hline
\end{tabular}

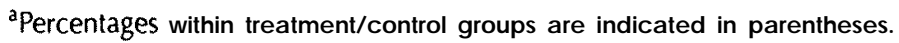

$b_{n}=3$ in all cases.

were only seen during the day and were therefore not included in the tabulation of species detected during nocturnal sampling.

Differences in species presence between control and treatment grids were minor. Jordan's salamander was dominant on all grids both before and after cutting, accounting for $5896 \%$ of the individuals captured during each sampling period (Table 1). Ocoee salamander was the second most abundant species in all cases. Blue Ridge two-lined salamander was found on each grid during pre-cutting sampling but was present on only three of the six grids during post-cutting sampling (one control grid and two treatment grids) in 1997 and one grid (a control) in 1998. Pygmy salamander was not found on either type of grid during post-cutting sampling in 1997 or on treatment grids in 1998; on grids where it did occur, it never accounted for more than $1.5 \%$ of the individuals captured.

The shelterwood harvest did not have a statistically significant effect on the abundance of Jordan's salamander over the 14-month period of the study $\left(F_{2,4}=\right.$ $0.55, p=0.54$; Table 2; Fig. 1). Estimated salamander abundance decreased from pre-cutting to post-cutting sampling, with a greater decline on the cut grids than on the uncut grids. Our power to demonstrate statistically an effect of timber harvest may have been reduced by variability among grids and the modest magnitude of the reduction in abundance, especially one year after the harvest.

Monthly precipitation was considerably lower during both post-cutting sampling periods (1997 and 1998) than during the 1997 pre-cutting period (U.S.D.A. Forest Service, Coweeta Hydrologic Laboratory, North Carolina, unpubl. data). Precipitation in the study area is normally lower in August and September than in June and July; however, August 1997, when most of the post-cutting sampling was done for that year, had less than $50 \%$ of the normal rainfall for that month. Rainfall during the first five months of 1998 was $117 \%$ of the normal value, but only $80 \%$ of the 


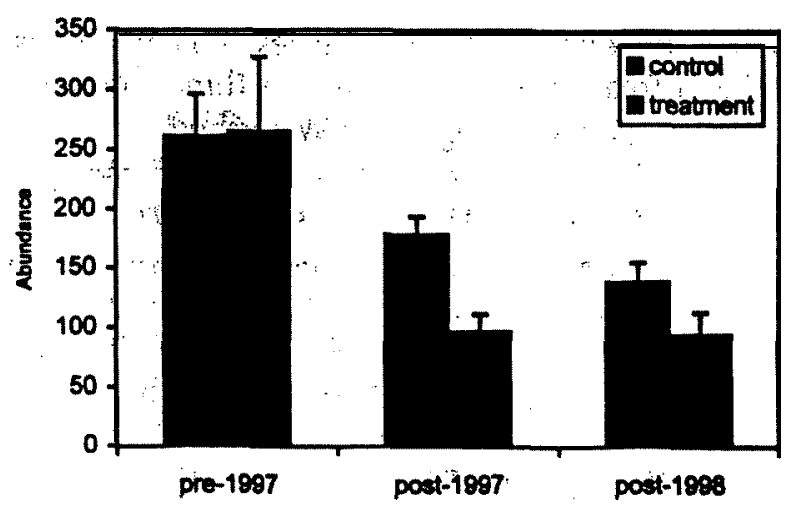

Fig. 1. Mean Jordan's salamander abundances $( \pm$ standard errors) for control grids (dark bars) and treatment grids (white bars) before shelterwood cutting, immediately after, and one year after cutting.

Table 2. Repeated Measures Analysis of Variance Table for Jordan's Salamander Abundance at Wine Springs Creek Watershed

\begin{tabular}{lcccc}
\hline \hline Source of variation & df & MS & F Statistic & $P$ \\
\hline Block & 2 & 1205.56 & & \\
Treatment & 1 & 7442.00 & 1.90 & 0.30 \\
Error (treatment) & 2 & 3926.00 & & \\
Time & 2 & 37709.39 & 7.67 & 0.102 \\
Time x Treatment & 2 & 2724.50 & 0.55 & $0.54^{\mathrm{a}}$ \\
Error (time) & 4 & 4913.50 & &, \\
\hline
\end{tabular}

${ }^{a} p$-value is based on Greenhouse-Ceisser adjustment for temporal autocorrelation to degrees of freedom.

normal value fell. during the two 1998 sampling months. The frequency of rainfall events was also lower during both post-cutting sampling periods than during precutting sampling. Not surprisingly, these drier post-cutting periods were associated with fewer salamander captures on both control and treatment grids.

During the 1997 post-cutting emigration. sampling, no salamanders were detected emigrating from their respective grids after cutting occurred. The total number of salamanders captured on emigration transects was 420 (mean $=12.71$ transect, S.E. = 1.27; Table 3), and none of these had been marked on any of the treatment grids prior to their capture. It is unlikely that salamanders emigrated from cut grids before emigration sampling was done, because no individually'marked salamanders were found outside the grid where they were originally marked during post-cutting abundance sampling. In fact, over half of the recaptured individuals 
Table 3. Numbers of Unmarked and Marked (in parentheses) Salamanders Captured on Emigration Transect? at Wine Spring Creek Watershed, September । 997

\begin{tabular}{|c|c|c|c|c|c|c|}
\hline & Treatment & Grid 1 & Treatment & Grid 2 & Treatment & Grid 3 \\
\hline Distance $(m)^{b}$ & Transect 1 & Transect 2 & Transect 1 & Transect 2 & Transect 1 & Transect 2 \\
\hline 10 & $1(0)$ & $2(0)$ & $30(0)$ & $22(0)$ & $10(0)$ & $12(0)$ \\
\hline 20 & $5(0)$ & $3(0)$ & $13(0)$ & $17(0)$ & $11(0)$ & $12(0)$ \\
\hline 30 & $2(0)$ & $5(0)$ & $18(0)$ & $15(0)$ & $20(0)$ & $16(0)$ \\
\hline 40 & $5(0)$ & $9(0)$ & $15(0)$ & $13(0)$ & $1 \mathrm{~s}(0)$ & $9(0)$ \\
\hline 50 & $2(0)$ & $5(0)$ & $21(0)$ & & $16(0)$ & $19(0)$ \\
\hline 60 & $-c$ & & & $18(0)$ & $14(0)$ & \\
\hline 70 & & & & $22(0)$ & & \\
\hline 80 & & & & $23(0)$ & & \\
\hline
\end{tabular}

"Transect 1 ran in the downslope direction; Transect 2 ran into the nearest uncut area.

bistance along the sampling line drawn from the grid boundary.

'Dash signs indicate areas that were beyond the end of the transect or were unsamplable due to extremely heavy slash.

within both control and treatment grids were found on either the same $1 \mathrm{~m}^{2}$ cell or the cell adjacent to where they were originally captured.

\section{DISCUSSION}

Some changes in the presence of individual species were apparent within the Wine Spring Creek sala mander community after timber cutting. Jordan's salamander clearly dominated the site before and immediately after cutting, as well as one year later. Two less common species showed noteworthy differences in occurrence before versus after the sheltenwood cut, although there was not a consistent contrast between control and treatment plots. Pygmy salamanders were encountered before cutting, but not immediately afterward on either type of grid. In 1998, this species was found on control grids only. Blue Ridge two-lined salamanders were found on all six grids before cutting, but on only three grids (two treatment grids and one control grid) immediately after cutting. In 1998 this species was found on only one grid (a control). The fact that it was missing from both treatment and control grids during 1997 and 1998 post-cutting sampling suggests that something affecting both types of grids caused the absence of this species. Blue Ridge two-lined salamanders were commonly observed on nights with light showers and during periods of ample precipitation during pre-cutting sampling. The drierpostcutting sampling conditions may have contributed to the absence of Blue Ridge two-lined salamanders. Because this species breeds in the fall, individuals may have already migrated to streamside breeding areas. 
We found no statistically signific ant reductions in J ordan's salamander abundance either one month or one year after timber harvest. Salamander abundances decreased from pre-cutting to post-cutting sampling, but declines occurred on both control and treatment grids. Two factors could account for the nonsignificant effect of shelterwood harvesting on Jordan's salamander abundance in our study site. First, the ana lysis may ind ic a te that J ordan's sa la mander popula tions in westem North Carolina are relatively resistant to the silvicultural treatment used in this study, and that the decreased numbers over time were a result of the drier post-harvest conditions rather than disturbance caused by the timber havest. The greater activity of many salamander species during wetter periods has been well documented (e.g., Heatwole, 1960, 1962; J a eger, 1980; Feder, 1983); during periods of drought, individuals typically spend more time under rocks and coarse woody debris and in sub'terranean burrows than on the surface foraging, making them more diffic ult to detect during sampling. After timber harvest, slash was left in place, a practice that several authors (Dodd, 1991; deMaynadier and Hunter, 1995) have suggested might mitigate some of the adverse effects of cutting. This explanation is consistent with two studies that reported no adverse effects of selective cutting on salamander distribution in New York. Pough et al. (1987) found that firewood harvest had no discemible effect on red-backed salamander (Plethodon cinereus) capture rates in a deciduous forest; Messere and Ducey (1998) similarly detected no adverse effects of selective cutting on this species. In contrast, Harpole and Haas (1999) compared salamander numbers before and after seven silvicultural treatments in an Appalachian hardwood forest in Virginia and found that numbers declined significantly in both shelterwood cuts and clearcuts, but not on control plots.

These studies and ours differ methodologic a lly in several respects. In our study area, J ordan's sala mander was the dominant species, whereas red-backed salamanderwas the dominant species in the other three studies. In addition, Ha rpole and Haas (I 999) tested the effect on the overall number of salamanders captured, and the other three studies tested individual species. Harpole and Haas (1999) also tested the significance of changes over time for each treatment independently, rather than analyzing treatments together as a single experiment, as was done in this study. The other two studies did not involve repeated sampling before and after different treatments. These methodological contrasts may account for the somewhat divergent findings on the effects of selective harvest on salamander populations in the eastem United States.

An altemative explanation for our failure to detect an adverse effect of shelterwood harvest on Jordan's salamander is that the shelterwood cut may have decreased the quality of the forest environment for salamanders at a broader scale, effectively reducing salamander abundance on both our cut and control grids (Petranka, 1999). Which explanation accounts for our findings is difficult to discem without a longer record and pre- and post-harvest data on habitat characteristics.

Methodologically, the difference in Jordan's salamander abundances between sampling periods in this study emphasize the potential effect that short-tem precipitation fluctuation has on salamander population estimates (Feder, 1983; Dupuis et al., 1995). Many studies that examine the effects of silvicultural treatements on salamander abundance are not based on repeated sampling to obtain abundance esti- 
mates. Because activity level, hence detectability, varies substantially with moisture levels (Jaeger, 1980; Feder, 1983), erroneous estimates may result if sites are sampled only once and under different moisture conditions. The high night-to-night variation in the number of salamanders captured on a given sampling grid at Wine Spring Creek (5-67 individuals) underscores the importance of repeated sampling to obtain accurate estimates of salamander abundance that can be compared among sites. Ideally, all sites should be sampled on the same night, or sampled on more than one occasion under similar weather conditions.

Post-logging emigration of salamanders was not detected in this study. No individually marked salamanders were found outside the grid where they were marked either during post-logging sampling along emigration transects or during abundance sampling on the grids. Although these findings do not support the suggestion made by Ash and Bruce (1994) that salamanders may emigrate out of timbered areas, emigration was only examined for a short period in this study, beginning three weeks after timber harvest occurred. Despite previous accounts of Jordan's salamander moving up to $60 \mathrm{~m}$ in a $24 \mathrm{hr}$ period (Madison and Shoop, 1970; Nishikawa, 1990), no salamanders marked in 1997 were found on grids in 1998 other than where they were originally marked the previous year. This argues against the possibility that emigration had already occurred by the time emigration transects were sampled. Petranka (1994) commented that salamanders are more likely to move underground and eventually die than emigrate away from cut stands under the desiccated conditions that follow logging. The results of this study, which suggest that emigration was insignificant after timber harvest, support that claim.

Results from the experimental shelterwood harvest at the Wine Spring Creek watershed suggest that shelterwood harvesting may have less of an adverse effect on salamander populations in the southern Appalachians than clearcutting, although more research is needed. The removal of only a percentage of total basal area in shelterwood cuts still creates a number of logging trails and disrupts the forest floor (deMaynadier and Hunter, 1995); yet, the islands of tree cover left intact allow the site to return more rapidly to a full canopy and provide a more consistent, moderate moisture regime (Harpole and Haas, 1999), which is necessary for salamander abundance to return to pre-cutting levels. More analysis of the tradeoffs between harvest yield and biological impacts associated with shelterwood cuts and other timber harvest methods is necessary to determine which method is best suited for long-term preservation of salamander populations in the southern Appalachians.

Acknowledgments: Funding for this research was provided by the U.S.D.A. Forest Service Southern Research Station's Wine Spring Creek Ecosystem Management Project, NSF grant BSR901 16611, and the Georgia Museum of Natural History. We thank Denise Madiens and Norman Hicks for assistance with data collection and analysis; Albert J. Parker, William M. Ford, and Andrew R. Blaustein for comments on an earlier draft of the manuscript; and Hartmut Walter and an anonymous referee for helpful advice.

\section{BIBLIOGRAPHY}

Ash, A. N. (1988) Disappearance of salamanders from clearcut plots. Journal of the Elisha Mitchell Society, Vol. 104, 1 16-I 22. 
Ash, A. N. (1995) Effects of clear-cutting on litter parameters in the southern Blue Ridge Mountains. Castanea, Vol. 60, 89-97.

Ash, A. N. (1997) Disappearance and return of Plethodontid salamanders to clearcut plots in the southern Blue Ridge Mountains. Conservation Biology, Vol. 11, 983-989.

Ash, A. N. and Bruce, R. C. (1994) Impacts of timber harvesting on salamanders. Conservation Biology, Vol. 8, 300-301.

Ash, A. N. and Pollock, K. H. (1999) Clearcuts, salamanders, and field studies. Conservation Biology, Vol. 13, 206-208.

Aubry, K. B. and Hall, P. A. (1991) Terrestrial amphibian communities in the southern Washington Cascade Range. In L.F. Ruggiero, K.B. Aubry, A.B. Carey, and M.H. Huff, technical coordinators, Wildlife and Vegetation Management of Unmanaged Doug/as-fir forests. USDA Forest Service General Technical Report PNW-285,327-339.

Buhlmann, K. A., Pague, C. A., Mitchell, J. C., and Glascow, R. B. (1988). Forestry operations and terrestrial salamanders: Techniques in a study of the cow knob salamander, Plethodon punctatus. In R. C. Szaro, K. E. Severson, and D. R. Patton, eds., Management of Amphibians, Reptiles, and Small Mammals in North America. USDA Forest Service General Technical Report RM-166, 38-44.

Bury, R. B. (1983) Differences in amphibian populations in logged and old-growth redwood forest. Northwest Science, Vol. 57, 167-I 78.

Bury, R. B., Corn, P. S., and Aubry, B. K. (1991) Regional patterns of terrestrial amphibian communities in Oregon and Washington. In L.F. Ruggiero, K.B. Aubry, A.B. Carey, and M.H. Huff, technical coordinators, Wildlife and Vegetation Management of Unmanaged Doug/as-fir Forests. USDA Forest Service General Technical Report PNW-285, 341-352.

Corn, P. S. and Bury, R. B. (1988) Douglas-fir forest in the Oregon and Washington Cascades: Relation of the herpetofauna to stand age and moisture. In R. C. Szaro, K. E. Severson, and D. R. Patton, eds., Management of Amphibians, Reptiles, and Small Mammals in North America. USDA Forest Service General Technical Report RM-166, 1 I-22.

deMaynadier, P. G. and Hunter, M. L., Jr. (1995) The relationship between forest management and amphibian ecology: A review of the North American literature. Environmental Reviews, Vol. 3, 230-261.

Dodd, C. K., Jr. (1991) The status of the red hills salamander, Phaeognathus hubrichti, Alabama, USA, 1976-I 988. Biological Conservation, Vol. 55, 57-75.

Donnelly, M. A. and Guyer, C. (1994) Estimating population size: Mark-recapture. In W. R. Heyer, M. A. Donnelly, R. W. McDiarmid, L.-A. C. Hayek, and M. S. Foster, eds., Measuring and Monitoring Biological Diversity: Standard Methods for Amphibians. Washington, DC: Smithsonian Institution Press, 183-200.

Donnelly, M. A., Guyer, C., Juterbock, J. W., and Aiford, R. A. (1994) Techniques for marking amphibians. In W. R. Heyer, M. A. Donnelly, R. W. McDiarmid, L.-A. C. Hayek, and M. S. Foster, eds., Measuring and Monitoring Biological Diversity: Standard Methods for Amphibians. Washington, DC: Smithsonian Institution Press, 277-284. 
Dupuis, L. A., Smith, J. N. M., and Bunnell, R. (1995) Relation of terrestrial-breeding amphibian abundance to tree-stand age. Conservation Biology, Vol. 9, 645653.

Feder, M. E. (1983) Integrating the ecology and physiology of Plethodontid salamanders. Herpetologica, Vol. 39, 291-310.

Ford, W. M., Chapman, B. R., Menzel, M. A., and Odom, R. H. (2001) Stand-age and habitat influences on salamanders in Appalachian cove hardwood forests. Forest Ecology and Management, in press.

Grialou, J. A., West, S. D. and Wilkins, R. N. (2000) The effects of forest clearcut harvesting and thinning on terrestrial salamanders. Journal of Wildlife Management, Vol. 64, 105-I 13.

Harper, C. A. and Guynn, D. C., Jr. (1998) Factors affecting salamander density and distribution within four forest types in the Southern Appalachian Mountains. Forest Ecology and Management, Vol. 114, 245-252.

Harpole, D. N. and Haas, C. A. (1999) Effects of seven silvicultural treatments on terrestrial salamanders. forest Ecology and Management, Vol. 114, 349-356.

Heatwole, H. (1960) Burrowing ability and behavioral responses to desiccation of the salamander, Plethodon cinereus. Ecology, Vol. 41, 661-668.

Heatwole, H. (1962) Environmental factors influencing local distribution and activity of the salamander Plethodon cinereus. Ecology, Vol. 43, 460-472.

Herbeck, L. A. and Larsen, D. R. (1999) Plethodontid salamander response to silvicultural practices in Missouri Ozark Forests. Conservation Biology, Vol. 13,623632.

Jaeger, R. G. (1980) Fluctuations in prey availability and food limitation for a terrestrial salamander. Oecologia, Vol. 44, 335-341.

Jaeger, R. G. and Inger, R.I. (1994) Standard techniques for inventory and monitoring: Quadrat sampling. In W. R. Heyer, M. A. Donnelly, R. W. McDiarmid, L.-A. C. Hayek, and M. S. Foster, eds., Measuring and Monitoring Biological Diversity: Standard Methods for Amphibians. Washington, DC: Smithsonian Institution Press, 97-103.

Kendall, W. L. (1999) Robustness of closed capture-recapture methods to violations of the closure assumption. Ecology, Vol. 80, 2517-2525.

Madison, D. M. and Shoop, C. R. (1970) Homing behavior, orientation, and home range of salamanders tagged with Tantalum-I 82. Science, Vol. 1 68, 1484-I 487.

Messere, M. and Ducey, P. K. (1998) Forest floor distribution of northern redback salamanders, Plethodon cinereus, in relation to canopy gaps: First year following selective logging. Forest Ecology and Management, Vol. 107, 319-324.

Milliken, G. A. and Johnson, D. E. (1992) Analysis of Messy Data: Designed Experiments. Volume 1. New York, NY: Chapman and Hall.

National Climatic Data Center. (1998) U. S. monthly precipitation for cooperative and NWS sites, updated August 12, 1998. Ashville, NC: National Climatic Data Center, on web @ http://www.ncdc.noaa.gov/ol/climate/online/coop-precip.html (digital database TD3220).

Nishikawa, K. C. (1990) Intraspecific spatial relationships of two species of terrestrial salamanders. Copeia, Vol. 1990, 418-426. 
Otis, D. L, Burnham, K. P., White, G. C., and Anderson, D. R. (1978) Statistic al Inference from Capture Data on Closed Animal Populations. Wa shington, DC: Wild life Society, Wild life Monographs, No. 62.

Owenby, J. R. and Ezell, D. S. (1992) Month/y Station Normals of Temperature, Precipitation, and Heating and Cooling Degree Days 196 l-1990, North Carolina. Ashville, NC: National C limatic Data Center, Climatography of the United States, No. 81.

Petranka, J. W. (1994) Response to impact of timber harvesting on salamanders. Conservation Biology, Vol. 8, 302-304.

Petranka, J. W. (1999) Recovery of salamanders after clearcutting in the southem Appala chians: A critique of Ash's estimates. Conservation Biology, Vol. 13, 203205.

Petranka, J. W., Brannon, M. P., Hopey, M. E., and Smith, C. K. (1994) Effects of timber harvesting on low elevation populations of southem Appalachian salamanders. forest Ecology and Management, Vol. 67, 135-147.

Petranka, J. W., Eldridge, M. E., and Haley, K. E. (1993) Effects of timber ha rvesting on so uthem Appa lac hian sa la manders. Conservation Biology, Vol. 7, 363-370.

Pough, F. H., Smith, E. M., Rhodes, D. H., and Collazo, A. (1987) The abundance of salamanders in forest stands with different histories of disturbance. Forest Ecology and Management, Vol. 20, I-9.

Raphael, M. G. (1988) Long-term trends in abundance of amphibians and reptiles and mammals in Douglas-fir forests of northwestem Califomia. In R. C. Sza ro, K. E. Severson, and D. R. Patton, eds., Management of Amphibians, Reptiles, and Small Mamma/s in North America. USDA Forest Service General Technical Report RM-166, 23-3 1.

Raymond, L. R. and Hardy, L. M. (1991) Effects of a clearcut on a population of the mole salamander Ambystoma tadpoideum, in an adjacent unaltered forest. Journal of Herpetology, Vol. 25, 509-512.

Ross, B., Fredericksen, T., Ross, E., Hoffman, W., Morison, M. L, Beyea, J., Lester, M. B., J ohnson, B. N. and Fredericksen, N. J . (2000) Relative abundance and species richness of herpetofauna in forest stands in Pennsylvania. Forest Science, Vol. 46, 139-I 46.

Smith, D. M., Larson, B. C., Kelty, M. J. and Ashton, I? M. S. (1997) The Practice of Silviculture: Applied Forest Ecology, 9th ed. New York: J ohn Wiley and Sons.

White, G. C., Anderson, D. R., Burnham, K. P., and Otis, D. L. (1982) Capturerecapture and removal methods for sampling closed populations. Los Alamos, NM: Los Alamos National Laboratory, LA-8787-NERP. 